\title{
Qualitative Methodology: Survey of Lifestyle of Albanian Youth in Macedonia
}

\author{
AbdyInaser Sinani \\ State University of Tetovo,llindenska p.n.1200 Tetovo, \\ nasersinani@yahoo.com
}

\section{Doi:10.5901/jesr.2014.v4n2p294}

\begin{abstract}
In the time when culture is becoming more powerfully consumed, changes are being made fast and radical in every segment of society, life styles are being more visible, more distinct and much more intriguing even for methodologists, who, more and more, for the research treatments have styles of living and methods and new methodology strategies. Sociology as a social science, through social context, follows the changes, explains trends and tries to understand the structure of social reality. This research represents a preliminary effort of the insight of understanding and essence of life style of the youth generation of albanians in Macedonia, phenomena and process of living in global conditions, a little or not at all explored in our areas. In this work is examined the usage of quantitative methodology, through ethnographic access and talking technique (deep life interview), in the context of researching the interdependence of life style and free time, physical activity and everyday life of the albanian youth generation from Macedonia. The research firstly claims to offer answers for the importance of physical activity in the life style of elderly, and secondly, could the material status, educational degree, marital status affect in the living style of albanian youth show high scale. Without any doubt, albanian youth show high scale of interest and motivation for physical activity and healthy life style, as they highlight physical activity and sport as their basic postulate for the healthy life. The research has shown that sport and physical activity, to the albanian youth generation from Macedonia, neither closely pursue life style trends. The results from this research suggest a multidimensional access of studying the life style of the youth generation of albanians in Macedonia, because they are less, they impose further researches.
\end{abstract}

Keywords: methodology, qualitative research, life style, albanian youth.

"Walking is the safest way to health" G. Seume

\section{Introduction}

The purpose of this paper is to explore the lifestyle of young Albanians in Macedonia, to provide clear response to trends and the way of living of young people. The long transition crisis, the high rate of unemployment, lack of perspective, has deeply reflected in the life and the way of thinking and living of young Albanians in Macedonia. As a theoretical framework for this survey has been used the theory of reasoned action (Theory on Reasoned Action, http://www.med.upenn.edu/hbhe4/part2-ch4-theory-of-reasoned-action.shtml), by putting forward a hypothetical model in which, based on attitudes, the assessment of behavior results, motivation to meet the indicators of behavior in sports, physical and health activity, as well as the attitude towards the healthy living. In this model as additional indicators are also included variables on values, interest for sport and orientation interest. Through lifestyle is reflected the way of life, values and individual attitudes by constructing the sense of identity. The style of living is an individual category, conditioned by the social environment. Conceived as such, Chaney, 2003:23, puts the lifestyle in relation to individual satisfaction of needs. The authors of this problem emphasize that, lifestyles that are characteristic of our time, as an action model of personal choice and facilitate the individuals to be distinguished between them, their identities, statuses, peculiarities and social differences. Social contextualization and everyday life as part of a modernism represents a challenge of higher level. The sociologist who uses qualitative approach is placed within the research itself; the conversations are detailed, with the aim of getting as many information as possible, and intense description of the context and event, which occur in the natural environment, at work, in the resting areas, family, school, etc. The term can be used in the most diverse spheres of social life and in different scales of communication and generalization; as such, the lifestyle very soon will not have any importance and at the same time will include everything (Kolundriq-Tomic, 1998:9). The increased concern of sociologists for research of the lifestyle in the 80's and the 90's of the last century, especially in developed countries, came as a result of the strengthening of social relations and stressed individuality, which, instead of group identifications, develop and emphasize the individuality, the interests and personal solutions. 
Lifestyle, as a measure of multidimensional behavior, relies on a greater number of individual specific behavior, constitutes a great number of observation or reaction by providing high level of security of results obtained. In this research took place 450 participants from 16 years of age up to the age of 26. The sample is intentional, and it is comprised of Albanian youth in Macedonia, by gender, profession, area of study or school. In this research is used the qualitative methodology, through the ethnographic approach and the conversational technique (deep vital interview), as a mixed methodological strategy in the context of research on youth lifestyles, research on the interdependence of leisure time, physical activity and everyday life of youth in the Republic of Macedonia, in the effort of understanding of development, vital dynamism, their relations with friends, their opinion on politics, religious beliefs, expectations from life, the future, desires, demands and pleasures or frustrations with the challenges of the time. The purpose of qualitative approach in this research is to describe the life of youth in the original form, without breaking their everyday life by the researcher, putting the total emphasize of treatment with all the segments and forms of its appearance. These dimensions of life and youth lifestyle will be explained through behavioral model, as an expressive explanation (behavior in leisure time and consumption specimen); interactive behavior (circle of contacts, affiliation and forms of interaction, for example ways of socialization, the use of cell phone, behavior in the work place; evaluation behavior (orientation values, attitudes, cultural traditions and affinities, for example, religious, political, patriotic attitude, attitude to music, etc., and at the cognitive behavior: self-observance, and observance of the social world.

\section{Lifestyle of Albanian Youth in the Rep. of Macedonia}

Understanding of the lifestyle in this research is convergent, equally oriented in external indicators based on analysis of orientations, attitudes, values and expectations of youth. Research has proven that three social areas, 1) culture (free time), 2) evaluating orientations, and 3) beauty as consumption, affect each other when determining the youth's lifestyle. With the help of variables on the behavioral orientation of at least four basic areas of life of young Albanians in Macedonia such as the school/faculty, family, leisure time and social activity, variables by which the pleasures of the following components are measured, like: socialization, cultural and creative needs, existential needs, with the help of which were investigated many lifestyles of Albanian youth in Macedonia: intellectual engagement style, traditional style, sport and physical culture, conflicting relations with parents, neglecting and inertia, religious and political commitment, consumption and fashion. In this research were also considered socio-demographic and personality features.

This research proves that for the analysis of the Albanian youth lifestyle crucial is the behavior and orientation, while as lifestyles dominate the traditional style of living, lifestyles of negligence and apathy, religious lifestyle, lifestyles of the "conflict" with parents, consumer's and privileges lifestyle and political engagement lifestyle. Less present lifestyles among Albanian youth are the lifestyle of intellectual engagement, lifestyle of sports and physical activity, lifestyle of behavior and independence.

Participants' sampling

\begin{tabular}{|l|c|}
\hline All participants & Number of participants \\
- Boys & 450 \\
- Girls & 220 \\
- High school students- & 230 \\
(III and IV year) & 100 \\
- Students & 220 \\
- Employees & 130 \\
(up to the age of 26) & \\
\hline
\end{tabular}

Table 1

As it was expected the domination of religious and traditional style, it was unexpected the preferences for active political engagement, low tendencies for independence and intellectual commitment, where the official data indicate that in the Republic of Macedonia, in the last ten years, over 70 per cent of the Albanian youth have completed the studies or are still studying. It seems that Albanian youth do not show enough interest for education and knowledge, while higher education has become trashy.

Within sports lifestyle and physical engagement it is included the healthy lifestyle. This way of living and lifestyle is closely related to health, nutrition, physical activity, sedentary way of living, smoking, alcohol, drugs, rest and sleep, sexual health, body weight, stress, oral health, risky behavior, etc. The healthy way of living of youth is certainly related to sports, physical exercises and body health culture, a style which prefers health, physical exercises and getting 
involved in sports. This way of living has positive impact on the improvement of community health. Although sport and physical activity are part of the life style of a considerable number of children in the Republic of Macedonia, however, young people become more and more passive, cultivating the boredom, neglect and sitting style. Dealing with the phone (as an object of game, even as obsession), watching TV, computer games, social networks together with other youth activities while sitting, are increasingly subject to review the mode of spending the free time by the youth and are labeled as probable cause of the sense of apathy, isolation, neglect: they result in reduced physical activity of youth. A situation described above, seems to be more present in the way of living of the Albanian youth in Macedonia. Researching by different authors (Sallis, Prochaska and Taylor, 2000) have proven that interdependence among youth's physical activity is associated with gender, age, depression, goals, previous physical activity and sports in the community, the habit of sitting after school or work (as a negative correlation), parents' influence and the possibilities for physical activity and sports (as positive correlation). Research has shown that there are a number of different behaviors among youth which are strongly related with physical activity and health. The focus is put on the correlation between physical activity and smoking. Result: smoking is closely related with the reduced physical activity, while regular sport and physical activity is associated with those young people who do not smoke. Respondents' answers have proven the link between smoking and the consumption of fruit and vegetables, and in some cases even the forgetfulness of breakfast.

\section{Conclusion and Recommendations}

The results obtained suggest for all the complexity of lifestyles and the correlation between the variables and the expected difference of the various elements in relation to gender, school and profession. Indicators of interest for sports deviate enough from the usualness, but are expected results: The sample shows higher level of interest, not for sports games, but for games of chance. The research has proven what we all knew, that all young people aged 16 and above play almost every day a game of chance, more often sports betting. Young Albanians continue to like football as number one sport, other sports are listed without any priority. It is important that the girls do not deviate from this orientation. The most favored sports among Albanian youth after football are the following: formula 1, volleyball, basketball, handball, skiing, wrestling, in the meanwhile modern sports, golf, swimming, cycling, dancing, parachuting, tennis are much less present among Albanian youth in Macedonia. In general the Albanian youth has positive attitude towards physical and health culture and healthy way of living, boys have more positive attitude towards sports and girls have the same opinion as boys when it comes to healthy way of living. The young participants in the sample despite the optimism for the future are aware of the fact that the situation in Macedonia is still bad and insecure. For them, finding a job and having secure life in Macedonia is a dream. Many of the young people (74\%) are attracted by the idea to temporarily leave their country for a job or better education and a professional career in one of the most developed countries. A considerable part of Albanian youth of Macedonia see their future in the engagement in one of political parties (63\%), as the only opportunity for employment or professional career. Smoking marijuana is less fashionable trend by the young people (only $10 \%$ are mentioning it). But there is not a small percentage that, in these uncertain times, turns to religion (43\%), sometimes even more than their parents. Albanian youth in Macedonia spends a considerable portion of their time with the media, watching television and listening to music and on social networks (92\%). Most of the Albanian youth, even in Macedonia are connected to the Internet, and about nine out of ten young people questioned, claim to have access to the Internet, regardless of dwelling place or gender. Social networks and the chat are two most mentioned reasons why young people use the Internet, because they like to chat with friends, relatives, etc. According to the preferences a new trend of Internet access through mobile phones has greatly expanded the opportunities to get connected. Many teenagers claim to use Facebook via phone and spend more time on the Internet using social networks. Foreign music is listened more $(64 \%)$ than the folkloric one (28\%), followed by political events and foreign films. News is also followed by a significant percentage (40\%). It is interesting to note that more than 1 in 3 girls watch soap operas daily.

It is interesting that healthy food is another popular trend among young Albanians in Macedonia with $77 \%$ of responses. Values associated with the outer appearance, fashion, as a respectable social status and healthy food, are considered as the most fashionable among the youth. The three most mentioned trends when the youth was asked are: to look good (95\%), have a smart phone (87\%) and being independent (74\%). On the question what is fashionable: the majority of responses were: to look good. For them to look good is prestige, a need to be accepted in a social circle, to find a job and to establish a relationship. Topics related to sexual life generally are considered taboo and very individual (92\%), especially when discussed with parents or other family members. The third most common activity is going out with friends, about $76 \%$ of the young Albanians claim to do so in their spare time. The youth, high school students as a representation group, equally tend to spend the free time with their friends. Besides going to school, gender and 
residence also affect the time spent with friends. In girls this percentage is lower than in boys. Doing sports is low in the pyramid of preferences of young Albanians of Macedonia. The largest number of them prefers to do physical activities and sports, but only one out of five of the young people interviewed regularly do sports or physical activity. Civic engagement is not fashionable trend among young people of Macedonia. This preference is little practiced by young people. Smoking marijuana is less fashionable trend among young Albanians because only one of the 20 respondents had any experience with it. Every twentieth respondent fears obesity. Family and friends are the most trusted social institutions for Albanian youngsters in Macedonia. Every second respondent admits the tight connection and trust with his relatives. Engaging in volunteer and charity work is low. Only one in ten young people interviewed were engaged in volunteering projects during the past 12 months. Their most frequent reason was low engagement in volunteering charity or civic initiatives seem to be associated with the lack of organized initiatives, rather than a negative perception or resistance against volunteering itself.

Each of the young people expresses a desire to participate in civic initiatives.

\section{References}

Despotović, LJ., Jovović, S.(1998). Odrastanje u košmarima tranzicije. Novi Sad: Istočnik.

Koković, D. (2007). Fenomenologija slobodnog vremena. Novi Sad: Tims.

Lenz,B.K.(2004).Tobacco, depression, and lifestyle choices in the pivotal early college years. Journal of American college health, 52(5), 213-219.

Jan Wright \& Judith Laverty. (2010). Young people, physical activity and transitions: Faculty of Education - Papers.

Miles, Matthew B. i Huberman, A. Michael (1994). Qualitative Data Analysis. An Expanded Sourcebook. 2nd Edition. Thousand Oakes: Sage.

Markuś,Damir.(2011). Razvoj modela za predvidanje životnog stila srednośkolca:Punim doktorature : Fakulteti i Kineziologjisë Universiteti i Zagrebit.

Moren, Edgar. (1979). Duh vremena. Beograd : Bigz..

Prot,F.,Gośnik,J.\&Bosnar,K(2003).The devoloment of sport preference structures.(pp.311).Salzburg:Institute of sport Science University of Salzburg.

Sheney, David. (2003) . Stilet jetësore. Beograd:Clio.

Śtigliç,Dubravka.(2012).Vlerat e përzgjedhjes së stilit jetësor. Zagreb:Grafos.

Tomić,I.Koludrović.(2002). Sociologija životnog stila: mikro-makro pristup:Zagreb: Jesenski i Turk.

Sallis JF, Prochaska JJ, Taylor WC.(2000). A review of correlates of physical activity of children and adolescents: Med Sci Sports Exerc. 2000 May;32(5):963-75.

http://www.ffst.hr/dokumenti/izdavastvo/studentski/sociologija/metodoloski\%20predmeti/3/4/strk-obiljezja\%20kvalitativnog\%20istrazi vanja.pdf, downloads, 23.04.2013.

Kërkimet cilësore në terren:khttp://89.188.32.41/download/mb_teren_istrazivanje.pdf, e downloads, 23.04.2013.

Perič,Ivan. (2007). Etnografski pristup u sociologiji: www.ffst.hr (Web faqja zyrtare e Fakultetit Filozofik, Split, 10.04.2007), downloads, 23.04.2013.

https://sites.google.com/site/sekcijakmi/ downloads , 23.04.2013.

www.nakladaslap.com/public/docs/knjige/Strategije\%2520k...

Proces kvalitativnih. Istraživanja/ downloads , 23.04.2013.

http://www.med.upenn.edu/hbhe4/part2-ch4-theory-of-reasoned-action.shtml

(www.mok.org.mk/Upload/Content/Documents/STRATEGIJA_ZA_R

Official documents:

Strategjia për zhvillimin e sportit në R. e Maqedonisë.

Strategjia kombëtare kundër varfërisë dhe përjashtimit social në R. e Maqedonisë 2010-2015. 